\title{
IGF1 induces up-regulation of steroidogenic and apoptotic regulatory genes via activation of phosphatidylinositol- dependent kinase/AKT in bovine granulosa cells
}

\author{
Arul Murugan Mani ${ }^{1,2}$, Mark A Fenwick ${ }^{1}$, Zhangrui Cheng ${ }^{1}$, Mohan K Sharma ${ }^{2}$, Dheer Singh ${ }^{2}$ \\ and D Claire Wathes ${ }^{1}$
}

${ }^{1}$ Reproduction Group, Department of Veterinary Basic Sciences, Royal Veterinary College, Hawkshead Lane, North Mymms, Hatfield, Hertfordshire AL9 7TA, UK and ${ }^{2}$ Animal Biochemistry Division, National Dairy Research Institute, Karnal, Haryana 132 001, India

Correspondence should be addressed to D C Wathes; Email: dcwathes@rvc.ac.uk

M A Fenwick is now at Division of Surgery, Oncology, Reproductive Biology and Anaesthetics (SORA), Faculty of Medicine, Imperial College London, Institute of Reproductive and Developmental Biology, Hammersmith Hospital, London W12 0NN, UK

\begin{abstract}
IGF1, a potent stimulator of cellular proliferation, differentiation and development, regulates granulosa cell steroidogenesis and apoptosis during follicular development. Depending upon species and stage of follicular growth, IGF1 acts on granulosa cell steroidogenesis either alone or together with FSH. We examined the mechanism of action of IGF1 in bovine granulosa cells in serum-free culture without insulin to determine its potential role in the regulation of steroidogenic and apoptotic regulatory gene expression and to investigate the interaction of FSH with IGF1 on this mechanism. Bovine granulosa cells treated with IGF1 demonstrated a significant increase in $17 \beta$-oestradiol $\left(\mathrm{OE}_{2}\right)$ production, cell number and in mRNA expression of CYP11A1, HSD3B1, CYP19A1, BAX, type 1 IGF receptor (IGF1R) and FSHR, while FSH alone had no significant effects. IGF1 or FSH alone or both together had no effect on $B C L 2$ expression. IGF1 with FSH resulted in a synergistic increase in granulosa cell number and in mRNA expression of CYP19A1 and IGF1R without altering $\mathrm{OE}_{2}$ production. IGF1 stimulated the phosphoinositide $3^{\prime}$-OH kinase (PI3K) but not the MAPK pathway in granulosa cells, as evidenced by increased phosphorylation of AKT but not extracellularregulated kinase 1/2. Addition of the PI3K pathway inhibitor LY294002 (but not the MAPK pathway inhibitor PD98059) abrogated the increased expression of genes induced by IGF1. IGF1 therefore up-regulates the steroidogenic and apoptotic regulatory genes via activation of PI3K/AKT in bovine granulosa cells. The synergistic action of IGF1 with FSH is of likely key importance for the development of small antral follicles before selection; subsequently, other factors such as LH may also become necessary for continued cell survival.

Reproduction (2010) 139 139-151
\end{abstract}

\section{Introduction}

$\mathrm{FSH}$ is an important pituitary hormone which controls granulosa cell steroidogenesis in the mammalian ovary by interacting with specific receptors located on granulosa cells (Richards 1994). The steroidogenic potential of granulosa cells can be modulated by locally produced growth factors acting through endocrine, paracrine and autocrine mechanisms, such that the modulation of granulosa cell steroidogenesis involves a complex interaction of both extra- and intra-ovarian signals. Insulin-like growth factor 1 (IGF1) plays a central role in these interactions with respect to both steroidogenesis and survival responses (Adashi \& Roban 1992, Giudice 1992, Armstrong \& Webb 1997).
The most important role of IGF1 appears to be reliant on its ability to synergize with gonadotrophins and to amplify their steroidogenic output (Adashi et al. 1985, 1988, Veldhuis et al. 1986, Urban et al. 1990, Balasubramanian et al. 1997). There are, however, species differences in these responses (deMoura et al. 1997, Chung et al. 1998, Devoto et al. 1999, Mamluk et al. 1999, Silverman et al. 1999), which may in part relate to the differing types of oestrous cycle. Cows are monovulatory species. At regular intervals during the bovine oestrous cycle, a group of small antral follicles grow rapidly from about 1 to $5 \mathrm{~mm}$ in size. Growth during this phase is dependent on gonadotrophin secretion and follicular production of both oestradiol $\left(\mathrm{OE}_{2}\right)$ and inhibin $\mathrm{A}$ increases, so circulating 
FSH concentrations fall. One follicle then achieves dominance, and is able to continue to grow in the face of declining and low FSH, whereas the remaining follicles within the wave undergo atresia (Webb et al. 2004, Mihm \& Evans 2008). This process is influenced by a variety of growth factors. Among these, IGF1 and insulin are of key importance in the cow as they can link follicular growth and steroid production with the metabolic status of the animal (Spicer \& Echternkamp 1995, Wathes et al. 2003). In ruminants, the major source of IGF1 in follicular fluid is the circulation (Funston et al. 1996, Perks et al. 1999) and there is substantial evidence that follicular maturation is compromised when cows are in negative energy balance and circulating concentrations of IGF1 and/or insulin are reduced (Wathes et al. 2003, Webb et al. 2004).

The effects of IGF1 are mediated through the type 1 IGF receptor (IGF1R), a transmembrane tyrosine kinase receptor that is structurally related to the insulin receptor. Depending upon the cell type, IGF1 activates the phosphoinositide $3^{\prime}-\mathrm{OH}$ kinase (PI3K) pathway and/or the MAPK pathway (Le Roith et al. 1995, Butt et al. 1999, Hancock 1999, Poretsky et al. 1999). PI3K signalling activates AKT (protein kinase B, PKB), an important mediator of proliferation and cell survival. Within the MAPK group, the extracellular-regulated kinase (ERK) can also regulate proliferation, differentiation and cell survival. Previous studies of both ovine and bovine follicles have suggested that both AKT and ERK signal transduction pathways are up-regulated during selection of the dominant follicle (Evans \& Martin 2000, Ryan et al. 2007). Furthermore, administration of specific inhibitors for ERK or AKT to ovine follicles during the first follicular wave of the cycle inhibited their further growth and $\mathrm{OE}_{2}$ production (Ryan et al. 2008). Despite their clear importance, the respective roles of these signalling pathways in the regulation of steroidogenesis and apoptosis by IGF1 alone or together with FSH in bovine granulosa cells still remain poorly understood.

While previous studies have shown that FSH and IGF1 can act synergistically to enhance follicular development, the mechanisms underlying this interaction remain uncertain (Richards et al. 2002). Furthermore, most previous studies involving cultured cattle granulosa cells have either provided serum during the first hours of culture or have pretreated the culture plates with serum to facilitate cell adhesion and increase cell viability (Langhout et al. 1991, Kawate et al. 1993, Wrathall \& Knight 1993, Gong et al. 1994). Under these conditions, the cells luteinize spontaneously, independently of gonadotrophins (Luck et al. 1990, Wathes et al. 1995) and rapidly loose their granulosa cell phenotype including CYP19A1 activity (Roberts \& Echternkamp 1994). Therefore, we used a serum-free system previously developed for bovine granulosa cells in which they maintain expression and activity of CYP19A1 and remain responsive to physiological concentrations of FSH and growth factors (Gutierrez et al. 1997).

It is also common practice in granulosa cell culture to add insulin to the medium. While insulin and IGF1 have distinct receptors (IGF1R and IR respectively), many of the downstream intracellular events resulting from ligand-induced receptor activation are very similar. Furthermore, at high concentrations insulin can cross react with the IGF1R, and when both receptors are present in the same cells IGF1R-IR hybrid receptors can form, which bind both IGF1 and insulin (Siddle et al. 2001, Le Roith 2003). In order to identify the specific effects of IGF1, we therefore tested IGF1 in the absence of any insulin.

The primary aim of the experiments was thus to investigate the dose-dependent and synergistic effects of IGF1 and FSH in the absence of insulin on granulosa cells obtained from small to medium-sized follicles, the stage when follicle selection is occurring and many follicles become atretic. Cell number, $\mathrm{OE}_{2}$ production and mRNA expression of steroidogenic (CYP11A1, HSD3B1 and CYP19A1) and apoptotic regulatory $(B C L 2$ and $B A X)$ genes, and genes encoding the IGF and FSH receptors (IGF1R and FSHR) were all measured under the same experimental conditions. The second aim was to determine the pathway(s) by which IGF1 exerts its effects on mRNA expression of selected genes and to investigate whether FSH influences the effects of IGF1 on these signalling pathways.

\section{Results}

Isolated granulosa cells were cultured for an initial $48 \mathrm{~h}$ establishment period in medium supplemented with androstenedione $\left(10^{-7} \mathrm{M}\right)$, low dose insulin $(10 \mathrm{ng} / \mathrm{ml})$, FSH $(1 \mathrm{ng} / \mathrm{ml})$ and low dose IGF1 $(1 \mathrm{ng} / \mathrm{ml})$ as described in more detail in the Materials and Methods section. Following this, the medium was replaced and that used in the experimental procedures continued to include androstenedione, but not insulin. Different treatment doses of IGF1, FSH or a combination were added as outlined below for the individual experiments.

\section{Cell morphology and number}

Shortly after seeding, granulosa cells were dispersed throughout the well with occasional clumps. After the initial $48 \mathrm{~h}$ of culture, cells were grouped into aggregates, similar to the spherical appearance of granulosa cells in vivo, which were attached to the culture plate by enlarged, flattened fibroblast-like cells present at the bottom of the clumps. There were significantly more granulosa cells present after culture for a further $48 \mathrm{~h}$ in the presence of 50 and $100 \mathrm{ng} / \mathrm{ml}$ of IGF1 in comparison 
Table 1 Effects of insulin-like growth factor 1 (IGF1) and FSH on bovine granulosa cell number.

\begin{tabular}{llllll}
\hline Expt. 1 & IGF1 $(\mathrm{ng} / \mathrm{ml})$ & 0 & 1 & 50 & 100 \\
& Absorbance & $0.65 \pm 0.03^{\mathrm{a}}$ & $0.79 \pm 0.05^{\mathrm{a}}$ & $1.85 \pm 0.22^{\mathrm{b}}$ & $2.07 \pm 0.17^{\mathrm{b}}$ \\
& FSH (ng/ml) & 0 & 1 & 25 & 50 \\
Expt. 2 & Absorbance & $0.7 \pm 0.05$ & $0.68 \pm 0.03$ & $0.73 \pm 0.04$ & $0.74 \pm 0.01$ \\
& (ng/ml) & 0 & FSH $(25)$ & IGF1 $(50)$ & FSH $(25)+I G F 1(50)$ \\
& Absorbance & $0.7 \pm 0.03^{\mathrm{c}}$ & $0.96 \pm 0.1^{\mathrm{c}}$ & $1.33 \pm 0.21^{\mathrm{d}}$ & $1.98 \pm 0.11^{\mathrm{e}}$ \\
\hline
\end{tabular}

Cells were treated with different doses of IGF1, FSH and its combination as indicated in the table for $48 \mathrm{~h}$ in serum-free culture. Cell proliferation was assessed by CellTiter 96 Aqueous One Solution (Promega), and the values are given as absorbance values. Data from three separate batches of cells were analysed by mixed model analysis, and results are presented as the mean \pm s.E.M.: $\mathrm{a}<\mathrm{b}, P<0.001 ; \mathrm{c}<\mathrm{d}<\mathrm{e}, P<0.001$.

with the untreated cells, whereas the $1 \mathrm{ng} / \mathrm{ml}$ dose of IGF1 had no effect (Table 1). More fibroblast-like cells were also noted in the presence of the higher doses of IGF1 (data not shown). In contrast, FSH alone (1, 25 and $50 \mathrm{ng} / \mathrm{ml}$ ) did not produce any significant effects on granulosa cell number. There was, however, a synergistic increase in cell number when $\mathrm{FSH}(25 \mathrm{ng} / \mathrm{ml})$ was added with IGF1 (50 ng/ml; Table 1).

\section{Effects of IGF1 and FSH on steroidogenesis}

Granulosa cells were treated for $48 \mathrm{~h}$ with different doses of IGF1 and FSH alone or in combination. There was a significant increase in mRNA expression of CYP11A1, HSD3B1 and CYP19A1, and in $\mathrm{OE}_{2}$ production with 50 and $100 \mathrm{ng} / \mathrm{ml}$ IGF1 but no effect of the lowest $1 \mathrm{ng} / \mathrm{ml}$ dose. Although the difference between 50 and $100 \mathrm{ng} / \mathrm{ml}$ IGF1 was not significant, the maximum values were seen with the $50 \mathrm{ng} / \mathrm{ml}$ IGF1 treatment. In contrast, the different doses of FSH (1, 25 and $50 \mathrm{ng} / \mathrm{ml})$ did not produce any significant effect on the above (Fig. 1). In a separate set of experiments, $\mathrm{FSH}(25 \mathrm{ng} / \mathrm{ml})$ in combination with IGF1 $(50 \mathrm{ng} / \mathrm{ml})$ stimulated a further 2.2-fold increase in CYP19A1 mRNA over IGF1 alone, but without altering $\mathrm{OE}_{2}$ production. The combined treatment did not affect mRNA expression of CYP11A1 or HSD3B1 compared with IGF1 alone (Fig. 2).

\section{Effects of IGF1 and FSH on the apoptotic regulatory genes $B C L 2$ and $B A X$}

The effects of IGF1 and/or FSH on mRNA expression of the apoptotic regulatory genes $B C L 2$ (anti-apoptotic) and $B A X$ (pro-apoptotic) were also measured. BCL2 mRNA was not affected by treatment with IGF1 or FSH either alone (Fig. 3A) or both together (Fig. 2D). Interestingly, IGF1 alone at 50 and $100 \mathrm{ng} / \mathrm{ml}$ increased the levels of $B A X$ mRNA transcript. On the other hand, the highest dose of $\mathrm{FSH}(50 \mathrm{ng} / \mathrm{ml})$ significantly reduced $B A X$ expression (Fig. 3B). The stimulatory effect of IGF1 (50 $\mathrm{ng} / \mathrm{ml}$ ) on $B A X \mathrm{mRNA}$ expression was not, however, prevented by $\mathrm{FSH}(25 \mathrm{ng} / \mathrm{ml}$; Fig. 2E). These results suggest that IGF1 might also participate in the apoptotic pathway in granulosa cells.

\section{Type 1 IGF receptors and FSH receptors}

The effect of IGF1 and FSH on IGF1R and FSHR mRNA expression was tested using selected doses, which had been shown to alter cell number and CYP19A1 mRNA expression. Treatment with IGF1 $(50 \mathrm{ng} / \mathrm{ml})$ significantly $(P<0.05)$ enhanced mRNA expression of both IGF1R and $F S H R$, but FSH $(25 \mathrm{ng} / \mathrm{ml})$ had no effect (Table 2).
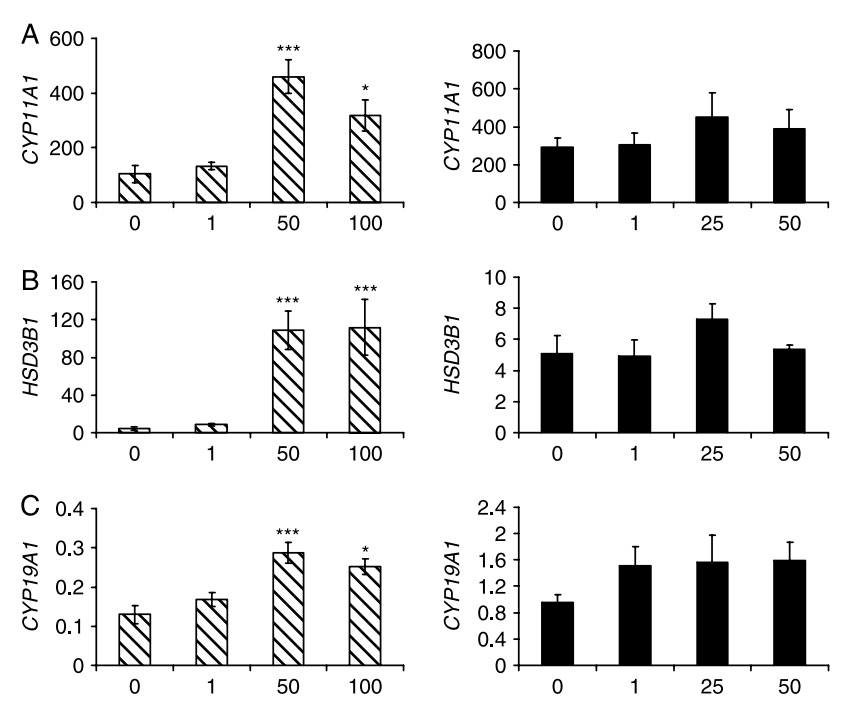

D
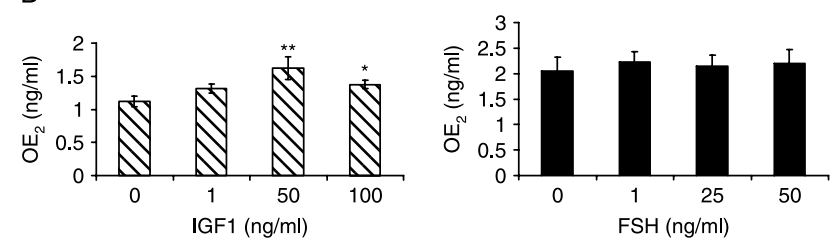

Figure 1 Dose-dependent effect of IGF1 and FSH on mRNA expression of the steroidogenic genes: (A) CYP11A1; (B) HSD3B1; (C) CYP19A1; and (D) on production of $\mathrm{OE}_{2}$ in bovine granulosa cells. Cells were cultured for an initial $48 \mathrm{~h}$ establishment period in supplemented serum-free medium. Cells were subsequently treated with IGF1 $(0,1,50$ and $100 \mathrm{ng} / \mathrm{ml})$ or $\mathrm{FSH}(0,1,25$ and $50 \mathrm{ng} / \mathrm{ml})$ for $48 \mathrm{~h}$. The reverse-transcribed RNA from cellular extracts was amplified by SYBR Green real-time PCR, and results are expressed as $\mathrm{fg} / \mu \mathrm{g}$ reversetranscribed RNA. Data from four separate batches of cells were analysed by mixed model analysis, and results are presented as the mean \pm S.E.M. For IGF1, $* P<0.05,{ }^{*} P<0.01$ and $* * * P<0.001$ versus 0 control. There were no significant treatment effects for $\mathrm{FSH}$. 

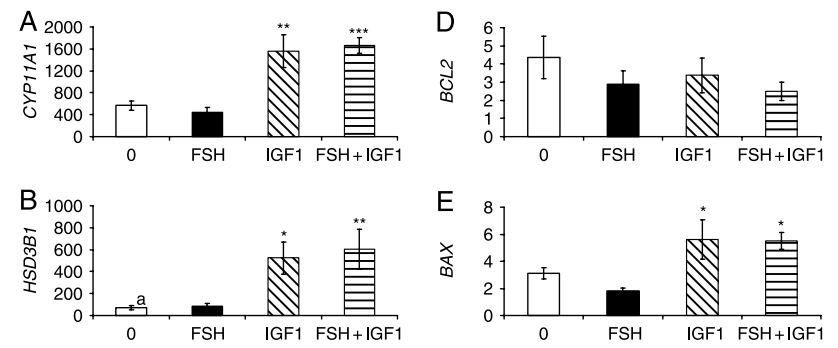

$\mathrm{F}$
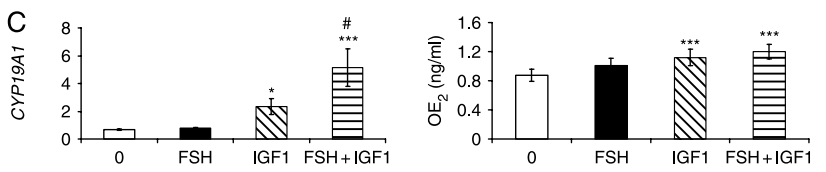

Figure 2 Effects of no treatment $(0$, control), FSH $(25 \mathrm{ng} / \mathrm{ml})$, IGF1 $(50 \mathrm{ng} / \mathrm{ml})$ or IGF1 + FSH on mRNA expression of: (A) CYP11A1; (B) HSD3B1; (C) CYP19A1; (D) BCL2; (E) BAX; and (F) production of $\mathrm{OE}_{2}$ in bovine granulosa cells. Cells were cultured for an initial $48 \mathrm{~h}$ establishment period in supplemented serum-free medium. Cells were subsequently treated as described for $48 \mathrm{~h}$. The reversetranscribed RNA from cellular extracts was amplified by SYBR Green real-time PCR, and results are expressed as $\mathrm{fg} / \mu \mathrm{g}$ reverse-transcribed RNA. Data from four separate batches of cells were analysed by mixed model analysis, and results are presented as the mean \pm S.E.M. ${ }^{*} P<0.05,{ }^{* *} P<0.01$ and ${ }^{* * *} P<0.001$ versus 0 control. ${ }^{*} P<0.05$ versus IGF1 treatment.

When the two hormones were added in combination, IGF1R was higher by 1.3 -fold than with IGF1 alone, whereas FSH completely prevented the IGF1 stimulated increase in the FSHR.

\section{Effects of IGF1 on the PI3K and MAPK pathways in bovine granulosa cells}

We next investigated the ability of IGF1 to induce phosphorylation of AKT and ERK in bovine granulosa cells. Cell lysates collected at different time periods from 0 to $48 \mathrm{~h}$ after treatment with $50 \mathrm{ng} / \mathrm{ml}$ IGF1 were subjected to immunoblotting with respective antibodies. The ratio between phosphorylated and total protein was then calculated. A very low level of phosphorylated AKT (p-AKT) was detected at $t=0 \mathrm{~h}$. This was immediately following the initial $48 \mathrm{~h}$ establishment period during which low dose insulin $(10 \mathrm{ng} / \mathrm{ml})$ and IGF1 $(1 \mathrm{ng} / \mathrm{ml})$ were both present. Overall time effects showed that values of $\mathrm{p}$-AKT were increased at $5 \mathrm{~min}(P<0.09)$ after addition of test medium containing $50 \mathrm{ng} / \mathrm{ml}$ IGF1, peaked at $15-60 \mathrm{~min}(P<0.001)$ and were still raised at $24 \mathrm{~h}(P<0.01)$, but had returned to baseline within $48 \mathrm{~h}$ (Fig. $4 \mathrm{~A}$ and $\mathrm{B}$ ). The greatest treatment response was seen in control cells (IGF1 alone), and this was significantly reduced by the MEK inhibitor PD98059 $(P<0.01)$ and to a greater extent by the PI3K inhibitor LY294002 either alone or together with PD98059 (both $P<0.001$ compared with control). The two forms of p-ERK, p-ERK1 (p44) and p-ERK2 (p42) were both detected at $t=0 \mathrm{~h}$. The overall treatment effect of inhibitors was highly significant $(P<0.001)$ with p-ERK $1 / 2$ progressively decreased by LY294002 alone $(P<0.05)$, PD98059 $(P<0.001)$ and the combined inhibitor treatment $(P<0.001)$. There was, however, no significant effect of time after IGF1 treatment and no treatment $\times$ time interaction. This implies that the MAPK pathway was not affected by IGF1 in the granulosa cells (Fig. 4C and D). The inhibition of p-ERK1/2 by LY294002 alone suggests that there is some degree of cross talk between the AKT and MAPK signalling pathways.

\section{Effects of IGF1 and FSH on AKT and ERK signalling}

We next examined the influence of FSH on IGF1activated AKT and ERK signalling in bovine granulosa cells. Cell lysates were collected at $30 \mathrm{~min}$ after IGF1 treatment with or without $\mathrm{FSH}$ in the presence or absence of inhibitors and subjected to immunoblotting with respective antibodies. The ratios between phosphorylated and total protein were then calculated. In unstimulated cells, the expression of p-AKT was not detected, but IGF1 significantly $(P<0.01)$ raised the levels of $\mathrm{p}$-AKT. FSH alone did not produce any detectable level of AKT phosphorylation (Fig. 5A). Although the combined IGF1/FSH treatment resulted in a numerically higher level of phosphorylation than with IGF1 alone, this difference did not achieve statistical significance. The relationship between FSH/IGF1 stimulation and AKT phosphorylation was further determined by pretreatment with specific inhibitors. The PI3K inhibitor LY294002 alone, or together with the MEK inhibitor PD98059, tended to $(P<0.08)$ reduce the
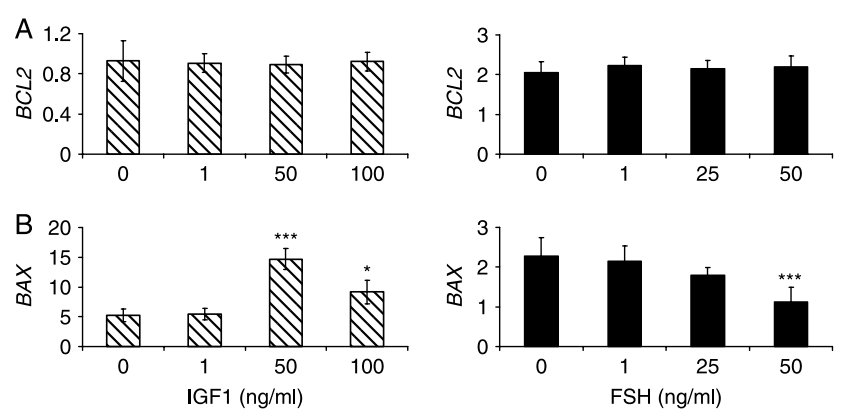

Figure 3 Dose-dependent effect of IGF1 and FSH on mRNA expression of (A) $B C L 2$ and (B) $B A X$ in bovine granulosa cells. Cells were cultured for an initial $48 \mathrm{~h}$ establishment period in supplemented serum-free medium. Cells were subsequently treated with IGF1 $(0,1,50$ and $100 \mathrm{ng} / \mathrm{ml})$ or $\mathrm{FSH}(0,1,25$ and $50 \mathrm{ng} / \mathrm{ml})$ for a further $48 \mathrm{~h}$ in serumfree culture. The reverse-transcribed RNA from cellular extracts was amplified by SYBR Green real-time PCR, and results are expressed as $\mathrm{fg} / \mu \mathrm{g}$ reverse-transcribed RNA. Data from four separate batches of cells were analysed by mixed model analysis, and results are presented as the mean \pm S.E.M. With addition of IGF1, there were significant increases in $B A X$, whereas FSH caused a significant decrease: ${ }^{*} P<0.05$, ${ }^{* * *} P<0.001$ versus 0 control. 
Table 2 Effects of insulin-like growth factor 1 (IGF1) and FSH on mRNA expression of IGF1R and FSHR in bovine granulosa cells.

\begin{tabular}{lcccr}
\hline & $\mathbf{0}$ & FSH & IGF1 & FSH+IGF1 \\
\hline IGF1R & $8.0 \pm 0.80^{\mathrm{a}}$ & $8.5 \pm 2.04^{\mathrm{a}}$ & $14.2 \pm 1.14^{\mathrm{b}}$ & $18.5 \pm 1.09^{\mathrm{c}}$ \\
FSHR & $0.9 \pm 0.12^{\mathrm{d}}$ & $0.8 \pm 0.20^{\mathrm{d}}$ & $2.0 \pm 0.21^{\mathrm{e}}$ & $0.9 \pm 0.06^{\mathrm{d}}$
\end{tabular}

Cells were treated with IGF1 $(50 \mathrm{ng} / \mathrm{ml})$ and/or FSH $(25 \mathrm{ng} / \mathrm{ml})$ for $48 \mathrm{~h}$ in serum-free culture. The reverse-transcribed RNA from cellular extracts was amplified by SYBR Green real-time PCR, and results are expressed as $\mathrm{fg} / \mathrm{\mu g}$ reverse-transcribed RNA. Data from three separate batches of cells were analysed by mixed model analysis, and results are presented as the mean \pm s.E.M.: $\mathrm{a}<\mathrm{b}, P<0.05 ; \mathrm{a}<\mathrm{c}, P<0.001$; $\mathrm{d}<\mathrm{e}, P<0.01$

p-AKT by 1.7- and 1.5-fold over the IGF1 + FSH-treated group, whereas PD98059 alone had no effect (Fig. 5A). Phosphorylated ERK was observed at $30 \mathrm{~min}$ in all the treatment groups, and its concentration at this time did not differ significantly between cells treated with IGF1 and/or FSH. Pretreatment with PD98059 together with LY294002 significantly $(P<0.05)$ inhibited phosphorylation of ERK1/2 when compared with the IGF1 alone, FSH alone or IGF1 + FSH treatments, whereas LY294002 alone had no significant effect (Fig. 5B).

A

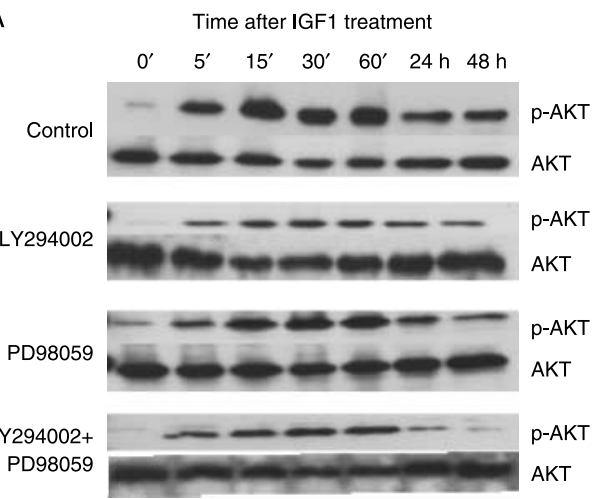

B

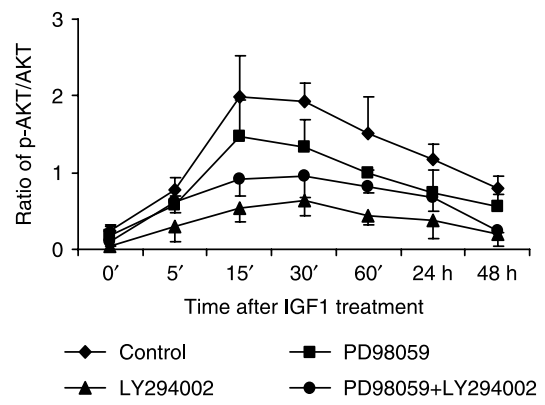

\section{Role of AKT and ERK pathways in IGF1-induced up-regulation of $m R N A$ expression of steroidogenic and apoptotic genes}

Finally, we determined whether the up-regulation of steroidogenesis and $B A X$ expression by IGF1 in bovine granulosa cells was mediated via AKT or ERK phosphorylation. Cells were treated with IGF1 for $48 \mathrm{~h}$ in the presence or absence of specific inhibitors. Pretreatment with the PI3K inhibitor LY294002 alone, or together with the MEK inhibitor PD98059, significantly $(P<0.05)$ inhibited the IGF1-induced increase in expression of mRNA for CYP11A1, HSD3B1 and CYP19A1. LY294002 pretreatment also tended $(P<0.1)$ to prevent any increase in $B A X$ and $\mathrm{OE}_{2}$ production (Fig. 6). These results suggested that IGF1 induced up-regulation of mRNA expression of steroidogenesis and $B A X$ requires activation of phosphatidylinositoldependent kinase/AKT in bovine granulosa cells.

\section{Discussion}

Cows undergo two or three waves of follicular development during each oestrous cycle. At the start of each wave, several small $1-5 \mathrm{~mm}$ follicles begin to grow and at this point the future dominant follicle and largest

C

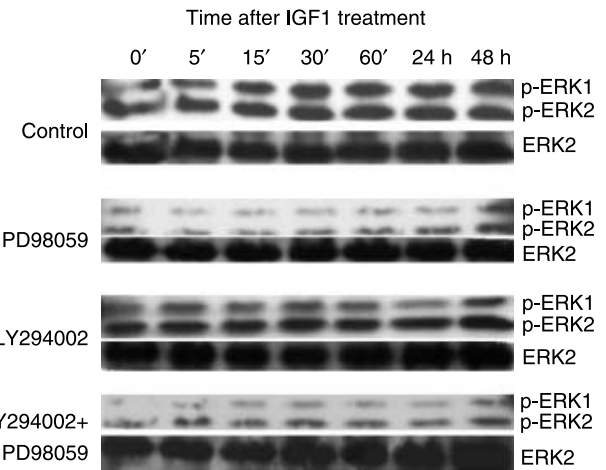

D

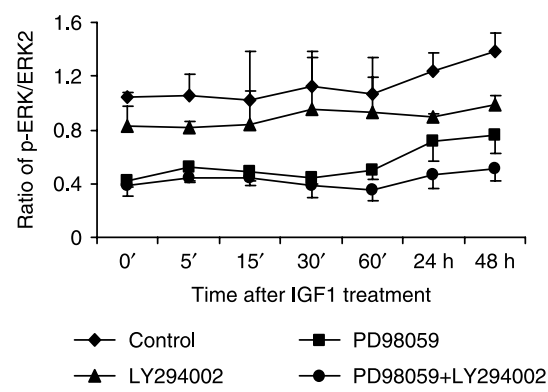

Figure 4 Activation of AKT and ERK by IGF1 in bovine granulosa cells. Cells were cultured for an initial $48 \mathrm{~h}$ establishment period in supplemented serum-free medium. Cells were subsequently pretreated for $30 \mathrm{~min}$ with no inhibitor (control), $10 \mu \mathrm{M} \mathrm{LY294002} \mathrm{(a} \mathrm{specific} \mathrm{PI3} \mathrm{kinase} \mathrm{inhibitor),}$ $15 \mu \mathrm{M}$ PD98059 (a specific MEK inhibitor) or both inhibitors in combination. IGF1 (50 ng/ml) was added and cells were collected for preparation of lysates at 0, 5, 15, 30 and $60 \mathrm{~min}$, and 24 and $48 \mathrm{~h}$. (A) Representative immunoblots showing phosphorylated (p-AKT) and total AKT. (B) Ratio of the signal intensities of p-AKT/total AKT. (C) Representative immunoblots showing p-ERK1/2 and total ERK2. (D) Ratio of the signal intensities of p-ERK1/2/total ERK2. Data from three separate batches of cells were analysed by mixed model analysis, and results are presented as the mean \pm s.E.M. In relation to $\mathrm{p}-\mathrm{AKT}$, there were highly significant $(P<0.001)$ effects of both time after IGF1 addition and inhibitor treatment, but no interaction (see text for further details). With respect to $\mathrm{p}$-ERK1/2, inhibitor treatment was highly significant $(P<0.001)$, but there was no significant effect of time after IGF1 and no treatment $\times$ time interaction as differences between treatments were already apparent before the addition of IGF1. 


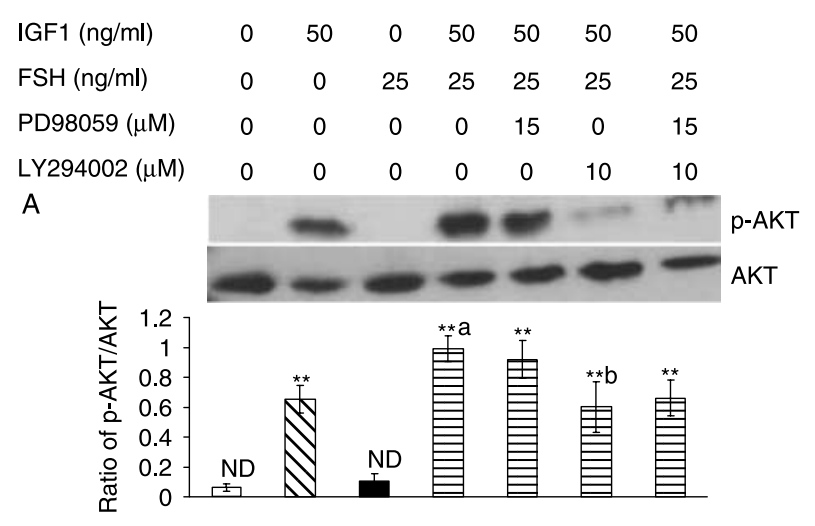

B

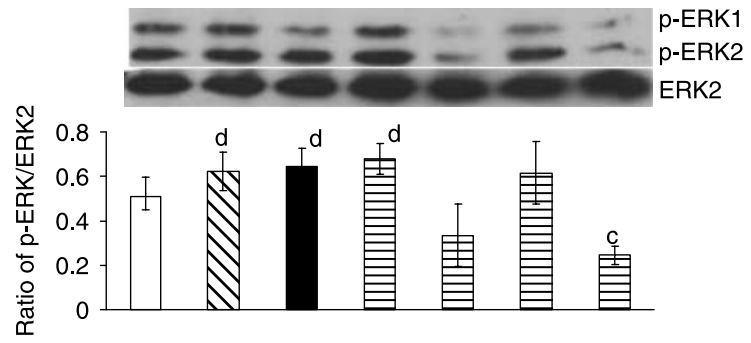

Figure 5 Effects of IGF1 and FSH on the activation of AKT and ERK in bovine granulosa cells. Cells were cultured for an initial $48 \mathrm{~h}$ establishment period in supplemented serum-free medium. Cells were subsequently pretreated with no inhibitor (control), $15 \mu \mathrm{M}$ PD98059 (a specific MEK inhibitor) and/or $10 \mu \mathrm{M}$ LY294002 (a specific PI3 kinase inhibitor) for $30 \mathrm{~min}$. Cells were then treated with IGF1 $(50 \mathrm{ng} / \mathrm{ml})$ or FSH $(25 \mathrm{ng} / \mathrm{ml})$ alone or in combination for $30 \mathrm{~min}$ in the presence or absence of the inhibitors. After incubation, cells were collected for preparation of lysates. (A) Representative immunoblots showing phosphorylated (p-AKT) and total AKT with histogram giving the ratio of the signal intensities of $p$-AKT/total AKT. (B) Representative immunoblots showing p-ERK1/2 and total ERK2 with histogram giving the ratio of the signal intensities of p-ERK1/2/total ERK2. Data from three separate batches of cells were analysed by mixed model analysis, and results are presented as the mean \pm s.E.M. For $\mathrm{p}-\mathrm{AKT}$, there was a highly significant overall treatment effect $(P<0.001)$. All combinations except FSH alone increased $\mathrm{p}$-AKT above the untreated control value $(* * P<0.01)$, which was not detectable (ND). There was a tendency for the addition of LY294002 to reduce the concentration of p-AKT below that found in the combined IGF1/FSH treatment $(b<a, P<0.08)$.

Neither IGF1 nor FSH alone or in combination increased p-ERK1/2 above control values. However, the combined PD98059+ LY294002 treatment reduced $p$-ERK1/2 concentrations $(c<d, P<0.05)$.

subordinate follicle are similar in size and growth rates. However, divergence soon occurs as $\mathrm{OE}_{2}$ production increases and the future dominant follicle continues to grow in the face of declining plasma FSH, whereas the subordinate follicles do not (Mihm et al. 2000, Ginther et al. 2001). This difference is probably achieved through enhanced responsiveness of the dominant follicle to gonadotrophin, an effect which is possibly mediated through higher concentrations of $\mathrm{OE}_{2}$ and free IGF1 present in the dominant follicle (Fortune et al. 2001, Quirk et al. 2004). In addition, granulosa cells from the selected dominant follicle increase their LH-binding capacity (Mihm \& Evans 2008). Little is currently known about the mechanisms involved in the synergistic effects of FSH with IGF1 on ovarian cell function in cattle.

In agreement with previous studies on bovine granulosa cells, IGF1 significantly enhanced granulosa cell number (Spicer et al. 1993, Gutierrez et al. 1997), whereas FSH alone did not (Langhout et al. 1991, Gong et al. 1993). Although Ryan et al. (2008) did report a small increase in cell number following FSH treatment, this may reflect differences in experimental design, in particular their inclusion of insulin in the medium during the FSH treatment. Previous studies have reported that FSH in the presence of $10 \mathrm{ng} / \mathrm{ml}$ of insulin stimulated granulosa cell proliferation in both cattle and sheep (Campbell et al. 1996, Gutierrez et al. 1997). Similarly in our experiments, FSH in the presence of $50 \mathrm{ng} / \mathrm{ml}$ of IGF1 did synergistically stimulate cell number when compared with IGF1 alone. This effect is more likely due to cell proliferation than enhanced cell survival, but it is possible that both mechanisms were operational as we could not differentiate between them with our experimental design. It is thus clear that FSH alone had no direct effect on granulosa cell proliferation, but did enhance the sensitivity of granulosa cells to the mitotic effect of IGF1. It is possible that this effect could be mediated through the reported increase in IGF1R following FSH treatment.

The most effective dose of IGF1 tested was $50 \mathrm{ng} / \mathrm{ml}$. This is slightly below the normal physiological range found in the follicular fluid of adult cows (e.g. 90-100 ng/ml, Funston et al. 1996). In the normal circulation, over $90 \%$ of IGF are complexed to IGF-binding proteins (IGFBPs; Jones \& Clemmons 1995) and the same is true within follicular fluid (Monget et al. 1993, Funston et al. 1996, Webb et al. 2004). Although we did not add any IGFBPs to the culture medium, the granulosa cells expressed mRNA for both IGFBP2 and IGFBP5 (AM Mani 2008, unpublished observations), so it is likely that these proteins were present in the medium and would, therefore, have influenced the bioavailability of the added IGF1. The dose-response studies found no effects of FSH alone at concentrations between 1 and $25 \mathrm{ng} / \mathrm{ml}$; only the higher dose of $25 \mathrm{ng} / \mathrm{ml}$ was subsequently tested in the synergistic experiments with IGF1. Basal concentrations of $\mathrm{FSH}$ in cows are around $20 \mathrm{ng} / \mathrm{ml}$, peaking at $30-60 \mathrm{ng} / \mathrm{ml}$ during the pre-ovulatory surge (Taya et al. 1991, Mihm et al. 1997), so this effective concentration was also within the normal physiological range.

Our current data demonstrated the effects of IGF1 on three genes controlling the rate of steroid hormone synthesis, namely CYP11A1, HSD3B1 and CYP19A1 and related this to steroidogenic output by measuring $\mathrm{OE}_{2}$ production. Treatment with IGF1 (50 and $100 \mathrm{ng} / \mathrm{ml}$ ) significantly enhanced the mRNA expression of CYP11A1, an inner mitochondrial membrane protein that catalyses the conversion of cholesterol to 

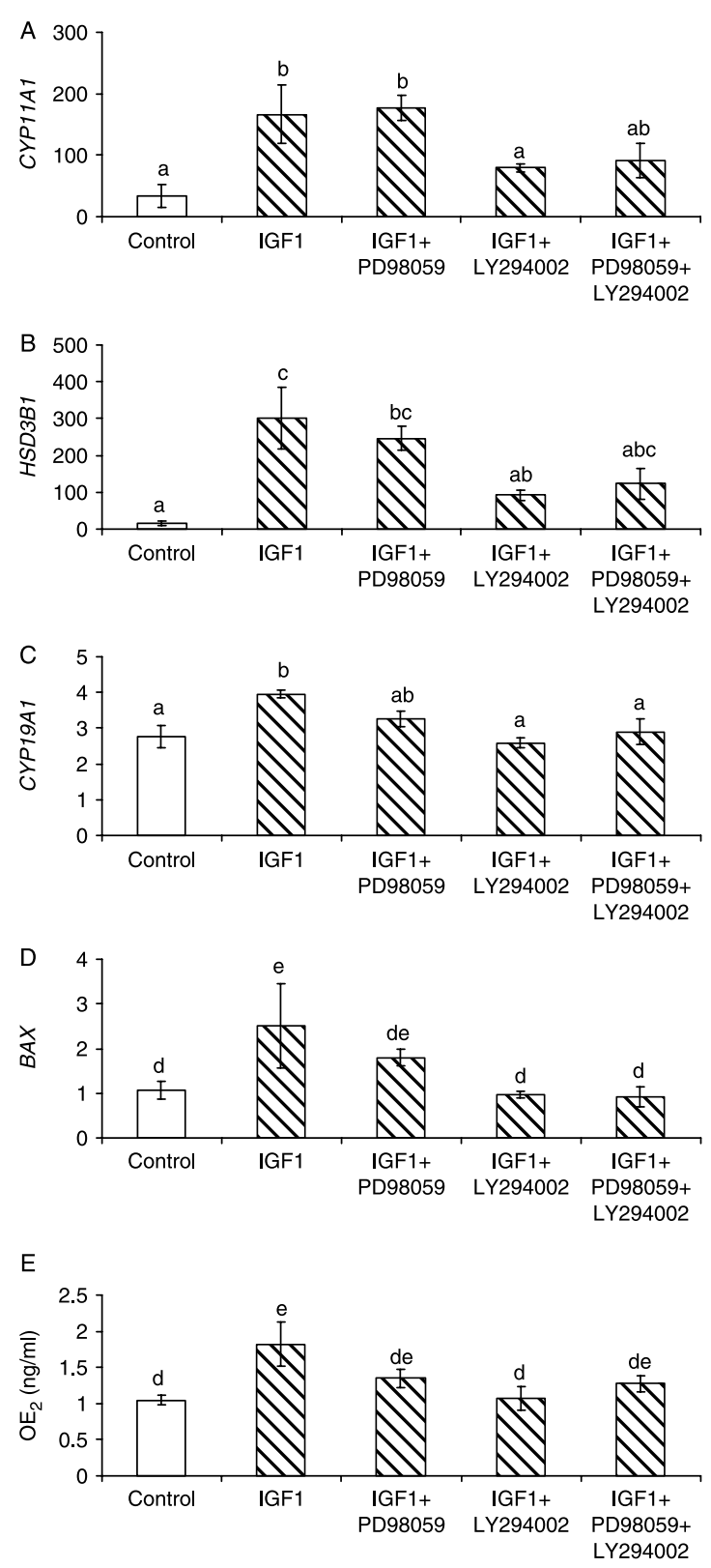

Figure 6 Effect of PD98059 and/or LY294002 on mRNA expression of the steroidogenic genes (A) CYP11A1; (B) HSD3B1; (C) CYP19A1; (D) BAX; and (E) $\mathrm{OE}_{2}$ production induced by IGF1 in bovine granulosa cells. Cells were cultured for an initial $48 \mathrm{~h}$ establishment period in supplemented serum-free medium. Cells were subsequently pretreated with no

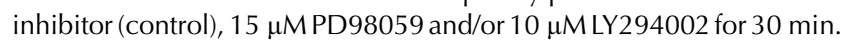
IGF1 $(50 \mathrm{ng} / \mathrm{ml})$ was then added and cells were cultured for a further $48 \mathrm{~h}$. After the treatment period, the spent media were used for measuring $\mathrm{OE}_{2}$ by RIA, and the cells were used for RNA isolation. The reverse-transcribed RNA was amplified by SYBR Green real-time $P C R$, and results are expressed as $\mathrm{fg} / \mu \mathrm{g}$ reverse-transcribed RNA. Data from two separate batches of cells were analysed by mixed model analysis, and results are presented as the mean \pm s.E.M. In all cases, the overall treatment effect was significant and IGF1 stimulated increases in comparison with the controls. This increase was consistently prevented by the presence of LY294002 either alone or together with PD98059. However, the addition of PD98059 alone did not significantly alter the response to IGF1: $\mathrm{a}<\mathrm{b}<\mathrm{c}, P<0.05 ; \mathrm{d}<\mathrm{e}, P<0.1$. pregnenolone. Similar results were previously observed in pig granulosa cells (Urban et al. 1990). In contrast, IGF1 alone did not produce any significant effect on CYP11A1 message in rat granulosa cells, requiring the presence of $\mathrm{FSH}$ to produce a synergistic stimulation (deMoura et al. 1997, Eimerl \& Orly 2002). FSH alone, or in synergy with IGF1, also enhanced mRNA expression of CYP11A1 in pig granulosa cells (Urban et al. 1994). Silva \& Price (2002) found that FSH but not insulin was important in maintaining CYP11A1 expression in bovine follicles. Surprisingly, in the present study, addition of FSH was without significant effect on CYP11A1 under either basal or IGF1-stimulated circumstances. These differences in results are currently hard to reconcile and indicate that the species, precise stage of follicular development and/or experimental treatment protocols can influence follicular CYP11A1 expression through mechanisms which remain to be fully elucidated.

The pregnenolone produced by the action of CYP11A1 is subsequently converted to progesterone by HSD3B. The enhancement of HSD3B1 transcripts by IGF1 treatment in the present study was consistent with work on rat granulosa cells (deMoura et al. 1997, Eimerl \& Orly 2002). FSH alone also induced HSD3B1 transcripts significantly in rat granulosa cells (deMoura et al. 1997), but not in the present study or in the work of Zheng et al. (2008), also on bovine tissue. In accord with previous work involving rat granulosa cells (deMoura et al. 1997, Eimerl \& Orly 2002), there was no significant synergistic effect of IGF1 and FSH on HSD3B1 expression. The increase in CYP11A1 and HSD3B1 stimulated by IGF1 may increase progesterone production per se, as well as providing precursor for $\mathrm{OE}_{2}$ production. In accord with this, both Schams et al. (1988) and Ryan et al. (2008) found that addition of IGF1 increased granulosa cells' progesterone production. A similar action of IGF1 may therefore be of particular importance in vivo after the $\mathrm{LH}$ surge when follicles are starting to luteinize.

Similarly, we found that IGF1 significantly enhanced expression of CYP19A1 mRNA and caused increased $\mathrm{OE}_{2}$ production. Unlike CYP11A1 and HSD3B1, the presence of FSH significantly enhanced IGF1-induced CYP19A1, consistent with previous reports in cultured bovine (Spicer et al. 2002, Ryan et al. 2008) and rat granulosa cells (Adashi et al. 1985). Although IGF1 and FSH produced a significant synergism on CYP19A1 expression, there was no accompanying alteration in $\mathrm{OE}_{2}$ production, possibly due to the relative sensitivities of the PCR and RIA methodologies employed. Moreover, it has been reported that, in the presence of $\mathrm{FSH}$, the maximal stimulatory effect achieved by IGF1 on $\mathrm{OE}_{2}$ production was only a fraction (8-20\%) of that observed for insulin (Spicer et al. 2002). FSH alone had no effect on $\mathrm{OE}_{2}$ production, but it significantly enhanced $\mathrm{OE}_{2}$ production by bovine granulosa cells obtained from 
heifers pretreated with pregnant mare serum gonadotrophin and cultured in the presence of $20-1000 \mathrm{ng} / \mathrm{ml}$ of insulin (Saumande 1991). Thus, insulin may be a more important stimulator of $\mathrm{OE}_{2}$ production by follicles than IGF1 in an FSH-rich environment.

To find out the apoptotic status of granulosa cells during IGF1 and FSH treatment, we also demonstrated the mRNA expression of $B C L 2$, an anti-apoptotic gene, and $B A X$, a pro-apoptotic gene. The ratio between these two is the critical determinant of cell fate, such that elevated BCL2 favours extended survival of cells, whereas increasing levels of $B A X$ expression accelerate cell death (Oltivai et al. 1993, Williams \& Smith 1993). IGF1 or FSH alone or together did not affect BCL2 mRNA expression. Higher doses of IGF1 (50 and $100 \mathrm{ng} / \mathrm{ml}$ ) increased, whereas higher doses of $\mathrm{FSH}$ $(50 \mathrm{ng} / \mathrm{ml})$ decreased, $B A X$ mRNA expression. However, the anti-apoptotic FSH did not affect the up-regulation of $B A X$ mRNA following IGF1. There was thus a significant decrease in the $B C L 2 / B A X$ ratio when cells were treated with IGF1 (data not shown). This could be detrimental to cells, whereas higher dose of FSH $(50 \mathrm{ng} / \mathrm{ml})$ given alone increased the ratio, indicating improved potential for survival. The rise in $B A X$ mRNA expression was not caused by reduced $I G F 1 R$, as mRNA expression of both genes was raised with the $50 \mathrm{ng} / \mathrm{ml}$ IGF1 dose. These results on gene expression contrast those on cell number, which was highest following IGF1 treatment and not influenced by FSH. Previous studies similarly found that IGF1 significantly stimulated cell proliferation in granulosa cell culture, but that FSH alone had no effect (Campbell et al. 1995, 1996).

It is possible that any decreases in cell number due to high concentrations of IGF1-inducing apoptosis may take longer than the $48 \mathrm{~h}$ culture period we tested to become manifest. Further studies involving a longer time course and incorporating TUNEL staining in addition to measurements of cell number as reported here would help to clarify this issue. According to Yang \& Rajamahendran (2000), a low dose of IGF1 $(10 \mathrm{ng} / \mathrm{ml})$ attenuated apoptosis, while a higher dose of $100 \mathrm{ng} / \mathrm{ml}$ increased apoptosis in cultured bovine granulosa cells. A combination of treatment with $\mathrm{FSH}$ $(1 \mathrm{ng} / \mathrm{ml})$ and IGF1 $(100 \mathrm{ng} / \mathrm{ml})$ inhibited apoptosis, and a similar finding was observed in pigs (Guthrie et al. 1997) in that both IGF1 and FSH suppressed apoptosis in cultured granulosa cells. The mechanism by which IGF1 at $50-100 \mathrm{ng} / \mathrm{ml}$ can increase $B A X$ expression (present study) and apoptosis (Yang \& Rajamahendran 2000 ) is not clear. However, a high concentration of IGF1 (evident at $>30 \mathrm{ng} / \mathrm{ml}$ ) inhibited oestrogen production by granulosa cells from small $(1-5 \mathrm{~mm})$ cattle follicles (Spicer et al. 1994a). The data are also consistent with the fact that rapidly dividing cells are the most susceptible to apoptosis (Quirk et al. 2004), so high IGF1 may increase the vulnerability of granulosa cells to apoptosis in the defined medium used here in which other essential survival factors present in serum (e.g. insulin and $\mathrm{LH}$ ) were lacking. Another possibility is that the induction of apoptosis requires an intermediary role of the IGFBP2 and -5 , which are present in granulosa cells and can inhibit IGF1 bioactivity in follicles (Ui et al. 1989, Monget et al. 1993). Increased IGF bioactivity as a result of decreased follicular IGFBP production may be part of the local control mechanism that drives follicle growth. Conversely, increased IGFBP production by atretic follicles would be expected to decrease IGF bioactivity and could be a key factor in the initiation of atresia (Ui et al. 1989, Monget et al. 1993).

Their respective receptors are obvious candidates by which IGF1 and FSH can induce up-regulation of steroidogenic and apoptotic regulatory genes. In cows, $I G F 1 R$, the physiological target of both IGF1 and IGF2, is expressed in granulosa cells throughout follicle development, with higher levels of expression in healthy than atretic follicles (Perks et al. 1999, Armstrong et al. 2000). In the present study, the levels of both IGF1R and FSHR were increased significantly when the cells were cultured with IGF1 $(50 \mathrm{ng} / \mathrm{ml})$. FSH alone had no effect on IGF1R mRNA, but FSH $(25 \mathrm{ng} / \mathrm{ml})$ in the presence of IGF1 $(50 \mathrm{ng} / \mathrm{ml})$ enhanced IGF1R. FSH alone did not alter FSHR mRNA, but it prevented the increase in FSHR mRNA found with IGF1 treatment alone. This effect of FSH was unexpected, but may be associated with enhanced differentiation of granulosa cells. These results clearly indicated that IGF1 can in part up-regulate steroidogenic and apoptotic regulatory pathways through increasing receptor numbers for both IGF1 and FSH. In contrast, Minegishi et al. (2000) reported a synergistic effect of IGF1 and FSH on FSHR expression in rat granulosa cells. Furthermore, they provided evidence that the addition of IGF1 increased the halflife of the FSHR transcript, thus providing a further mechanism by which IGF1 can affect FSH action. As the IGF1 treatment used here also increased $\mathrm{OE}_{2}$ production, it remains to be determined whether the effect on IGF1R was direct or mediated via $\mathrm{OE}_{2}$. Spicer et al. (1994b) previously reported that $\mathrm{OE}_{2}$ treatment can increase the number of IGF1R in granulosa cells from small bovine follicles.

The downstream mechanisms by which activated IGF1R influences the steroidogenic and apoptotic regulatory genes are poorly defined. The potential roles of the AKT and MAPK pathways in mediating the protective effect of IGF1 were examined because each of these pathways has been shown to have effects on cell survival as well as proliferation in a number of cell types (Gallaher et al. 2001). We present evidence that IGF1 stimulation alone caused an activation of $\mathrm{PKB} / \mathrm{AKT}$ in granulosa cells, as evidenced by increased phosphorylation of AKT. These results are consistent 
with reports that survival of bovine granulosa cells in serum-free culture medium in response to IGF1 in the presence of $100 \mathrm{ng} / \mathrm{ml}$ insulin is associated with increased phosphorylation of AKT (Hu et al. 2004). Moreover, we found that inhibition of the PI3K pathway by LY294002 reduced the IGF1-stimulated mRNA expression of CYP11A1, HSD3B1, CYP19A1, BAX and $\mathrm{OE}_{2}$ production. Similarly, addition of PI3K inhibitor significantly decreased the insulin-stimulated CYP19A1 mRNA levels and $\mathrm{OE}_{2}$ accumulation in bovine granulosa cells (Silva et al. 2006). Although there was a tendency for ERK1/2 phosphorylation to rise 24-48 h after the addition of IGF1 (Fig. 4), this was not statistically significant. A further complication was the finding that LY294002, a PI3 kinase inhibitor, also produced a modest reduction in the level of p-ERK $1 / 2$. This supports previous suggestions that there is some degree of cross talk between the AKT and MAPK signalling pathways (Kumar et al. 2008). In previous work on other cell types, IGF1 stimulated both PI3K and MAPK pathways, but only the PI3K pathway was required for protection against apoptosis (Kulik et al. 1997, Miller et al. 1997, Campana et al. 1999). Therefore, we concluded that IGF1-enhanced mRNA expression of steroidogenic and apoptotic regulatory genes was via the PI3K pathway and not by the MAPK pathway. It is possible that the enhancement of IGF1 action by FSH found in relation to cell number and increased expression of IGF1R and CYP19A1 was mediated via further increases in AKT signalling. Although the numerical increase in AKT following the combined IGF1 and FSH treatment failed to achieve statistical significance, such an effect was reported by Ryan et al. (2008).

In summary, our results show that FSH acts synergistically with IGF1 to increase cell number and expression of CYP19A1 mRNA in bovine granulosa cells, and that the actions of IGF1 involved the PI3K signalling cascade. The model we have used is most relevant to the growth phase of antral follicles during the start of a follicular wave. Our studies support a key role for IGF1 in the regulation of both proliferation and steroidogenesis in the dairy cow, where follicular development may be compromised in early lactation, in association with reduced circulating IGF1 concentrations (Wathes et al. 2003). Once selection occurs, the dominant follicle continues to grow and increase $\mathrm{OE}_{2}$ production, whereas the subordinate follicles undergo apoptosis. The increased $B A X$ mRNA expression found with IGF1 after $48 \mathrm{~h}$ in our serumfree culture system implies that apoptotic pathways were also up-regulated at this time. It is likely that further development at this stage would be dependent on the provision of $\mathrm{LH}$, insulin and possibly other additional factors, which may be necessary to promote continued survival of the dominant follicle.

\section{Materials and Methods}

\section{Reagents}

All culture media and additives as well as kinase inhibitors (LY294002 and PD98059) were purchased from Sigma Chemical Co. Ovine FSH (Ovagen; 15.6-19.6 mg potency per vial relative to NIADDK-oFSH-17) was from ICPbio (Auckland, New Zealand). Recombinant human IGF1 was from Bachem (St Helens, Merseyside, England). Antibody against $\mathrm{OE}_{2}$ was from Biogenesis (Poole, Dorset, UK). RNeasy mini kits were from Qiagen. Superscript first-strand synthesis system for RT-PCR was from Invitrogen. Absolute qPCR SYBR Green mix was from ABgene (Epsom, Surrey, UK). Rabbit antimouse p-AKT (Ser473, no. 9271) and total AKT antibodies (no. 9272) were obtained from Cell Signaling Technology (New England Biolabs (UK) Ltd, Hitchin, Hertfordshire, UK). Mouse anti-human p-ERK (Tyr204, sc-7383) and polyclonal goat antirat ERK2 (sc-154G) were from Santa Cruz Biotechnology, Inc. (Santa Cruz, CA, USA). HRP-conjugated rabbit anti-goat IgG and HRP-conjugated goat anti-rabbit IgG were from Pierce Biotechnology (Chester, Cheshire, UK). HRP-conjugated goat anti-mouse IgG was from BD Biosciences (Oxford, UK).

\section{Isolation and culture of granulosa cells}

Freshly excised bovine ovaries were obtained from the local abattoir and transported in $\mathrm{M} 199$ at $37^{\circ} \mathrm{C}(\sim 2 \mathrm{~h})$ and then processed immediately. Granulosa cells from follicles sized 2-8 mm were isolated and cultured in serum-free McCoy's 5A medium as previously described (Gutierrez et al. 1997). Briefly, follicles were isolated manually by dissection and selected for isolation of granulosa cells if they appeared healthy based on a transparent appearance, highly vascularized theca and clear follicular fluid without any visible debris. Follicles were hemisected and granulosa cells were obtained by flushing the hemisected shells with medium and collecting the cell-rich supernatant. Cells were plated at a density of $5 \times 10^{5}$ cells $/ \mathrm{ml}$ in 24-well plates (Iwaki, Osaka, Japan) using serum-free McCoy's $5 \mathrm{~A}$ medium supplemented with bicarbonate $(2.2 \mathrm{mg} / \mathrm{ml})$, penicillin $(100 \mathrm{IU} / \mathrm{ml})$, streptomycin $(100 \mu \mathrm{g} / \mathrm{ml})$, amphoterecin $B(1.25 \mu \mathrm{g} / \mathrm{ml})$, L-glutamine $(3 \mathrm{mM} / \mathrm{ml})$, BSA $(1 \mathrm{mg} / \mathrm{ml})$, androstenedione $\left(10^{-7} \mathrm{M}\right)$, transferrin $(2.5 \mu \mathrm{g} / \mathrm{ml})$, sodium selenite $(0.04 \mathrm{ng} / \mathrm{ml})$, bovine insulin $(10 \mathrm{ng} / \mathrm{ml})$, ovine $\mathrm{FSH}$ $(1 \mathrm{ng} / \mathrm{ml})$ and human rIGF1 $(1 \mathrm{ng} / \mathrm{ml})$. They were then cultured for a $48 \mathrm{~h}$ establishment period at $37{ }^{\circ} \mathrm{C}$ in humidified air with $5 \% \mathrm{CO}_{2}$. The hormone treatments during this initial phase were selected based on the study of Gutierrez et al. (1997) who established that this culture system could maintain a granulosa cell phenotype.

After the initial $48 \mathrm{~h}$ establishment period, the spent media were carefully removed and replaced with fresh medium prepared as above and including androstenedione, but without the other hormonal additives (insulin, FSH and IGF1) as standard. This was to remove the possibility that insulin might produce responses in addition to the IGF1 being tested. At this stage, cells were left untreated or were treated with different treatment doses of IGF1, FSH or a combination of both with or without inhibitors as indicated in the figure legends. After a further $48 \mathrm{~h}$ treatment period, media were carefully removed 
and stored at $-20{ }^{\circ} \mathrm{C}$ until assayed, and cells from triplicate wells were pooled and used for RNA isolation. In some experiments, cells were pretreated with vehicle $(0.007 \%$ DMSO) or inhibitors for $30 \mathrm{~min}$ before the addition of IGF1 $\pm \mathrm{FSH}$. In a separate series of experiments, cells from triplicate wells were collected separately and pooled for immunoblotting at various times from 0 to $48 \mathrm{~h}$ during the treatment period. For cell proliferation assay, cells $\left(50 \times 10^{3}\right)$ were plated in $250 \mu \mathrm{l}$ culture medium per well in 96-well plates (Iwaki), but other aspects of the experimental treatments remained the same.

\section{Monitoring cell growth and proliferation}

Growing cells were photographed using a Canon PowerShot A540 digital camera (6MP $4 \times$ Optical) attached to an inverted microscope after the initial $48 \mathrm{~h}$ establishment period and again after the $48 \mathrm{~h}$ treatment. Viable cell numbers were measured after the $48 \mathrm{~h}$ treatment period using the Cell Titer96 Aqueous One Solution Cell Proliferation Assay (Promega). For this, $20 \mu \mathrm{l}$ cell proliferation assay solution was added into each well of a 96-well culture plate containing cells in $100 \mu \mathrm{l}$ culture medium and incubated for $4 \mathrm{~h}$ at $37{ }^{\circ} \mathrm{C}$ with $5 \% \mathrm{CO}_{2}$. At the end of the incubation period, the quantity of formazan product was measured as absorbance at $490 \mathrm{~nm}$ using a 96 well ELISA plate reader. This was directly proportional to the number of living cells in culture. Each treatment was performed in triplicate upon each batch of cells and cells from each well were assayed individually.

\section{Hormone assay}

$\mathrm{OE}_{2}$ was measured in culture media by RIA as previously described (Lane \& Wathes 1998). The sensitivity of the assay was $40 \mathrm{pg} / \mathrm{ml}$. The intra- and inter-assay coefficients of variation were 7 and $9 \%$ respectively. Each treatment was performed in triplicate upon each batch of cells and media from each well were assayed individually.

\section{RNA isolation and RT}

Total RNA was isolated from cell cultures using an RNeasy mini kit (Qiagen) and quantitated using a NanoDrop spectrophotometer (ND-1000 Spectrophotometer, NanoDrop Technologies Inc., Wilmington, DE, USA). All samples had an A260/280 ratio of absorbance between 1.8 and 2.0. The integrity of isolated RNA was assessed by ethidium bromide stained as $28 \mathrm{~S}$ and $18 \mathrm{~S}$ ribosomal bands on agarose gel. Following DNase treatment (Promega Corporation), RNA was reverse-transcribed into first-strand cDNA using random primers and SuperScript II Rnase $\mathrm{H}^{-}$Reverse Transcriptase (Invitrogen Ltd, Life Technologies) according to the manufacturer's protocols.

\section{Primer design and optimization of RT-PCR}

Assays were designed for steroidogenic genes (CYP11A1, HSD3B1 and CYP19A1), apoptotic regulatory genes (BCL2 and $B A X)$ and receptors (IGF1R and FSHR). Primer sequences were taken from a previous reference (Fenwick et al. 2008) or were designed online using the Primer3 web software (http:// frodo.wi.mit.edu/primer3/input.htm) based on coding regions of core bovine nucleotide sequences available from NCBI (http://www.ncbi.nlm.nih.gov/) or Ensembl (http://www. ensembl.org). Wherever possible, primers were designed to amplify products spanning the boundary of at least two adjacent exons. All oligonucleotides were synthesized commercially as highly purified salt-free products (MWG-Biotech AG, London, UK). The primer sequences, accession number and expected product lengths are listed in Table 3.

For each gene, PCR conditions were optimized by conventional PCR amplification using Platinum PCR SuperMix containing Taq polymerase (Invitrogen Ltd, Life Technologies) and the addition of $50 \mathrm{ng}$ DNase-treated reverse-transcribed RNA and primers $(20 \mu \mathrm{M})$. Once optimized, external standards were prepared from cDNAs identical to real-time PCR products and purified using QIAquick PCR purification columns (Qiagen). The precise concentrations of purified cDNA product were determined using the NanoDrop ND-100 spectrophotometer, and products were then diluted in nuclease-free water and used as qPCR standards. The identity of the cDNA products was confirmed by DNA sequences analysis (Geneservice Ltd, Cambridge, UK).

\section{SYBR Green real-time PCR}

Gene transcripts were quantified by real-time PCR using the DNA engine Option 2 (MJ Research Inc., Waltham, MA, USA). For each assay, a mastermix was prepared that contained a final concentration of $2 \times$ Absolute qPCR SYBR Green mix (ABgene), $500 \mathrm{nM}$ forward and reverse primers and nucleasefree water. For all unknown samples measured, $20 \mu$ reactions were prepared in white tubes (TLS-0851, Bio-Rad) and sealed with optical clarity flat caps (TCS-0803, Bio-Rad). Each reaction containing the above mastermix was added with $50 \mathrm{ng}$ reverse-transcribed RNA and was analysed as duplicates. External standards were run on the same plate in triplicate $20 \mu \mathrm{l}$ reaction volumes. Thermal cycling conditions applied to each assay consisted of an initial Taq activation step at $95^{\circ} \mathrm{C}$ for 15 min followed by 38 cycles of denaturation, annealing, extension and an amplicon-specific fluorescence reading (Table 4). A melting curve analysis was performed for each amplicon between 50 and 95 to ensure any smaller nonspecific products such as dimers (if present) were melted prior to fluorescence acquisition.

All quantitative PCR results were recorded with the Opticon Monitor analysis software. Background fluorescence was subtracted using the global minimum function, and the threshold was manually placed in the linear amplification phase. For comparison of expression data, absolute values expressed as $\mathrm{fg} / \mu \mathrm{g}$ reverse-transcribed RNA were derived from the mean $C_{\mathrm{t}}$ value of all unknown samples. The stable expression levels of several genes were tested (data not shown) for normalization of qPCR data; however, no such transcripts were found to be satisfactory and therefore a set of highly pure and precise cDNA standards were generated to ascertain the absolute expression levels of unknown samples. Serial dilutions of each standard exhibited high amplification 
Table 3 Oligonucleotide primer sequences and expected amplicon size used for real-time PCR assays.

\begin{tabular}{|c|c|c|c|}
\hline Gene & Sequence $\left(5^{\prime} \rightarrow 3^{\prime}\right)$ & Size (bp) & Accession no. \\
\hline \multirow[t]{2}{*}{ CYP11A1 } & For: AGACTTGGAGGGACCATGTAGC & 117 & ENSBTAT \\
\hline & Rev: TGCCTGGGTAATTCCTAAATTC & & 00000009106 \\
\hline \multirow[t]{2}{*}{ HSD3B1 } & For: AATCCGGGTGCTAGACAAAGT & 111 & ENSBTAT \\
\hline & Rev: CACTGCTCATCCAGAATGTCTC & & 00000010992 \\
\hline \multirow[t]{2}{*}{ CYP19A1 } & For: TGGCTGTGCAGAAAGTATGAA & 127 & ENSBTAT \\
\hline & Rev: CAGTGGCGAAATCTATGCTGT & & 00000019823 \\
\hline \multirow[t]{2}{*}{$B C L 2$} & For: GTGGATGACCGAGTACCTGAAC & 124 & ENSBTAT \\
\hline & Rev: AGACAGCCAGGAGAAATCAAAC & & 00000025701 \\
\hline \multirow[t]{2}{*}{$B A X$} & For: GACATTGGACTTCCTTCGAGA & 126 & ENSBTAT \\
\hline & Rev: AGCACTCCAGCCACAAAGAT & & 00000017739 \\
\hline \multirow[t]{2}{*}{ IGF1R } & For: GATCCCGTGTTCTTCTACGTTC & 101 & X54980 \\
\hline & Rev: AAGCCTCCCACTATCAACAGAA & & \\
\hline \multirow[t]{2}{*}{ FSHR } & For: GCCAAGTCAACTTACCGCTT & 193 & NM174061 \\
\hline & Rev: TGACCCCTAGCCTGAGTCAT & & \\
\hline
\end{tabular}

CYP11A1, cytochrome P450 side chain cleavage; HSD3B1, 3ß-hydroxysteroid dehydrogenase type 1; CYP19A1, cytochrome P450 aromatase; $B C L 2$, B-cell lymphoma-2; $B A X, \mathrm{BCl}-2$ associated $\mathrm{X}$ protein; IGF1R, insulin-like growth factor receptor type $1 ; F S H R$, FSH receptor.

efficiencies (all $>0.91$ ) and linearity (all $>0.99$ ). For each batch of cells, cell isolation and RNA measurement were performed using cells pooled from triplicate culture wells. The RNA was then converted to cDNA and this was used to generate duplicate measurements by $\mathrm{qPCR}$, ensuring that equal amounts of cDNA were loaded into each well.

\section{Immunoblotting}

Cells were washed with ice-cold PBS ( $\mathrm{pH} 7.5)$ and the culture wells were aspirated to dryness. Then, lysis buffer $(63.5 \mathrm{mM}$ Tris-HCl (pH 6.8), 10\% (v/v) glycerol, 2\% (w/v) SDS, $10 \mu \mathrm{l}$ of $1 \times$ protease inhibitor cocktail (Calbiochem, Sandiego, CA, USA) and $200 \mathrm{mM}$ sodium orthovanadate) was added to the cells, which were then incubated on ice for $10 \mathrm{~min}$. The cells were scraped from the culture wells into $1.5 \mathrm{ml}$ microfuge tubes and were then boiled at $100{ }^{\circ} \mathrm{C}$ for $5 \mathrm{~min}$ and briefly centrifuged to pellet the cell debris, if present. After determination of approximate protein content using absorbance at $280 \mathrm{~nm}$ (NanoDrop ND-1000 spectrophotometer), bromophenol blue and $\beta$-mercaptoethanol were added to the samples to give final concentrations of $0.02 \%(\mathrm{w} / \mathrm{v})$ and $5 \%$ $(\mathrm{v} / \mathrm{v})$ respectively. The samples were then stored at $-20{ }^{\circ} \mathrm{C}$ until analysed.

Protein lysates $(100 \mu \mathrm{g})$ were separated by $10 \%$ SDS-PAGE and transferred to PVDF membranes (Millipore, Watford, Hertfordshire, UK). Membranes were blocked in Tris-buffered

Table 4 Specific cycling temperatures used for real-time PCR assays.

\begin{tabular}{lcccc}
\hline \multicolumn{5}{c}{ Temperature $\left({ }^{\circ} \mathrm{C}\right)$} \\
\cline { 2 - 5 } Gene & Denaturation & Annealing & Extension & $\begin{array}{c}\text { Fluorescence } \\
\text { acquisition }\end{array}$ \\
\hline CYP11A1 & 95 & 52.5 & 72 & 77 \\
HSD3B1 & 95 & 54.2 & 72 & 78.5 \\
CYP19A1 & 95 & 52.5 & 72 & 77 \\
BCL2 & 95 & 52.5 & 72 & 77 \\
BAX & 95 & 52.5 & 72 & 82.5 \\
IGF1R & 95 & 55.9 & 72 & 78.5 \\
FSHR & 95 & 52.5 & 72 & 81.5 \\
\hline
\end{tabular}

saline (TBS-T; $50 \mathrm{mM}$ Tris, $\mathrm{pH} 7.4,150 \mathrm{mM} \mathrm{NaCl}$ and $0.02 \%$ Tween-20) containing $10 \%(\mathrm{w} / \mathrm{v})$ non-fat milk for $2 \mathrm{~h}$ at room temperature with gentle agitation before incubating overnight in TBS-T-10\% BSA containing antibodies to p-AKT (dilution $1: 1000$ ) with gentle agitation at $4{ }^{\circ} \mathrm{C}$ or $\mathrm{p}$-ERK (dilution $1: 1000$ ) with maximum agitation at room temperature. Membranes were then washed, incubated with HRP-conjugated secondary antibodies in TBS-T for $1 \mathrm{~h}$ at room temperature and washed. A chemiluminescent signal was generated using enhanced chemiluminescence reagent (ECL Amersham Biosciences), and membranes were exposed to X-ray film (ECL Amersham Biosciences). After detection of p-AKT and p-ERK, membranes were stripped by immersing in stripping buffer $(6.25 \mathrm{mM}$ Tris- $-\mathrm{HCl}, \mathrm{pH} 6.7,2 \%(\mathrm{w} / \mathrm{v})$ SDS and $0.7 \%(\mathrm{v} / \mathrm{v})$ $\beta$-mercaptoethanol) and incubated for $30 \mathrm{~min}$ at $50{ }^{\circ} \mathrm{C}$. Stripped blots were washed, blocked and re-probed with antibodies for total AKT (dilution 1:1000) with gentle agitation at $4{ }^{\circ} \mathrm{C}$ or ERK2 (dilution 1:1000) with maximum agitation at room temperature overnight. Signals were quantified by densitometry of digitalized images using Bio-Rad Molecular Quantity One software, version 4.4.0, and the ratios of p-kinases to total kinases were calculated.

\section{Statistical analysis}

Data were analysed by mixed model analysis using SPSS v 17 (SPSS Inc., Chicago, IL, USA) using a random block design. This model assumes the variance within the block (in this case, each experimental batch of cultured granulosa cells) is homogeneous, whereas the variance between blocks may be heterogeneous. In this model, the treatments were taken as fixed effects and the batches (blocks) as random effects for correction of the difference between the batches. Within each batch, the experimental replicates were taken as repeated measurements. In time-course experiments, both treatment and time were included as fixed effects and their interaction was also tested. Bonferroni tests were used for comparison of means when overall significance (treatment effect of $P<0.05$ ) was observed. Each treatment was repeated on several separate batches of granulosa cells as reported in the figure legends. The values are presented as mean \pm s.E.M. 


\section{Declaration of interest}

The authors declare that there is no conflict of interest that would prejudice the impartiality of this scientific work.

\section{Funding}

A M Mani was supported by the Commonwealth Scholarship Commission, UK via a split-site doctoral scholarship 2006-2007.

\section{Acknowledgements}

We thank Dr W Marei and Ms A Miller for their help with collection of ovaries from the slaughterhouse. The authors also thank Dr D R E Abayasekara and Ms L Barton for their technical suggestions.

\section{References}

Adashi EY \& Roban RM 1992 Intraovarian regulation. Peptidergic signalling systems. Trends in Endocrinology and Metabolism 3 243-248.

Adashi EY, Resnick CE, Brodie AM, Svoboda ME \& Van Wky JJ 1985 Somatomedin-C mediated potentiation of follicle stimulating hormoneinduced aromatase activity of cultured rat granulosa cells. Endocrinology $1172313-2320$.

Adashi EY, Resnick CE, Hernandez ER, May JV, Kecht M, Svoboda ME \& Van Wyk JJ 1988 Insulin-like growth factor-I as an amplifier of follicle stimulating hormone action: studies on mechanism(s) and site(s) of action in cultured rat granulosa cells. Endocrinology 122 1583-1591.

Armstrong DG \& Webb R 1997 Ovarian follicular dominance: novel mechanisms and protein factors. Reviews of Reproduction 2 139-146.

Armstrong DG, Gutierrez CG, Baxter G, Glazyrin AL, Mann GE, Woad KJ, Hogg CO \& Webb R 2000 Expression of mRNA encoding IGF1, IGF1I and type 1 IGF receptor in bovine ovarian follicles. Journal of Endocrinology 165 101-113.

Balasubramanian K, Lavoie HA, Garmey JC, Stocco DM \& Veldhius JD 1997 Regulation of porcine granulosa cell steroidogenic acute regulatory protein (StAR) by IGF1: synergism with FSH or protein kinase A agonist. Endocrinology 138 433-439.

Butt AJ, Firth SM \& Baxter RC 1999 The IGF axis and programmed cell death. Immunology and Cell Biology 77 256-262.

Campana WM, Darin SJ \& O'Brein JS 1999 Phosphatidylinositol-3-kinase and Akt protein kinase mediate IGF1 and prosaptide-induced survival in Schwann cells. Journal of Neuroscience Research 57 332-341.

Campbell BK, Scaramuzzi RJ \& Webb R 1995 Control of antral follicle development and selection in sheep and cattle. Journal of Reproduction and Fertility Supplement 49 335-350.

Campbell BK, Scaramuzzi RJ \& Webb R 1996 Induction and maintenance of estradiol and immunoreactive inhibin production with FSH by ovine granulosa cells cultured in serum free media. Journal of Reproduction and Fertility 106 7-16.

Chung PH, Sandhoff TW \& McLean MP 1998 Hormone and prostaglandin $\mathrm{F}_{2}$ regulation of messenger ribonucleic acid encoding steroidogenic acute regulatory protein in human corpora lutea. Endocrine 81 153-160.

Devoto L, Christenson LK, MeAllister JM, Makrigiannakis A \& Strauss JF 1999 Insulin and insulin-like growth factor-I and -II modulate human granulosalutein cell steroidogenesis: enhancement of steroidogenic acute regulatory protein (StAR) expression. Molecular Human Reproduction 5 1003-1010.

Eimerl S \& Orly J 2002 Regulation of steroidogenic genes by insulin-like growth factor-I and follicle stimulating hormone: differential responses of cytochrome CYP19, steroidogenic acute regulatory protein and 3BHSD/ isomerase in rat granulosa cells. Biology of Reproduction 67 900-910.

Evans ACO \& Martin F 2000 Kinase pathways in dominant and subordinate ovarian follicles during the first wave of follicular development in sheep. Animal Reproduction Science 64 221-231.

Fenwick MA, Fitzpatrick R, Kenny DA, Diskin MG, Patton J, Murphy JJ \& Wathes DC 2008 Interrelationships between negative energy balance (NEB) and IGF regulation in liver of lactating dairy cows. Domestic Animal Endocrinology 34 31-44.
Fortune JE, Rivera GM, Evans ACO \& Turzillo AM 2001 Differentiation of dominant versus subordinate follicles in cattle. Biology of Reproduction 65 648-654.

Funston RN, Seidel GE, Klindt J \& Roberts AJ 1996 Insulin-like growth factor I and insulin-like growth factor-binding proteins in bovine serum and follicular fluid before and after the preovulatory surge of luteinizing hormone. Biology of Reproduction 55 1390-1396.

Gallaher BW, Hille R, Raile K \& Kiess W 2001 Apoptosis: live or die hardwork either way! Hormone and Metabolic Research 33 511-519.

Ginther OJ, Beg MA, Bergfelt DR, Donadeu FX \& Kot K 2001 Follicle selection in monovular species. Biology of Reproduction 65 638-647.

Giudice LC 1992 Insulin-like growth factors and ovarian development. Endocrine Reviews 13 641-669.

Gong J, McBride D, Bramley TA \& Webb R 1993 Effects of recombinant bovine somatotrophin, insulin-like growth factor-I and insulin on the proliferation of bovine granulosa cells in vivo. Journal of Endocrinology 139 67-75.

Gong JG, McBride D, Bramley TA \& Webb R 1994 Effects of recombinant bovine somatotrophin, insulin-like growth factor-I and insulin on bovine granulosa cell steroidogenesis in vitro. Journal of Endocrinology 143 157-164.

Guthrie HD, Garrett WM \& Cooper BS 1997 Follicle-stimulating hormone and insulin-like growth factor-I attenuate apoptosis in cultured porcine granulosa cells. Biology of Reproduction 58 390-396.

Gutierrez CG, Campbell BK \& Webb R 1997 Development of a long-term bovine granulosa cell culture system: induction and maintenance of estradiol production, response to follicle-stimulating hormone, and morphological characteristics. Biology of Reproduction 56 608-616.

Hancock JF 1999 Kinase cascades and apoptosis. In Signaling Pathways in Apoptosis, pp 123-146. Eds D Walters \& M Lavin. Amsterdam: Harwood Academic Publishers.

Hu CL, Cowan RG, Harman RM \& Quirk SM 2004 Cell cycle progression and activation of Akt kinase are required for insulin-like growth factor I mediated suppression of apoptosis in granulosa cells. Molecular Endocrinology 19 326-338.

Jones JI \& Clemmons DR 1995 Insulin-like growth factors and their binding proteins: biological actions. Endocrine Reviews 16 3-34.

Kawate N, Inaba T \& Mori J 1993 Effects of cortisone on the amounts of estradiol-17 $\beta$ and progesterone secreted and the number of luteinising hormone receptor in cultured bovine granulosa cells. Animal Reproduction Science 32 15-25.

Kulik G, Klippel A \& Weber MJ 1997 Antiapoptotic signaling by the insulinlike growth factor I receptor, phosphatidyl inositol 3 kinase and Akt. Molecular and Cellular Biology 17 1595-1606.

Kumar N, Afeyan R, Kim HD \& Lauffenburger DA 2008 Multipathway model enables prediction of kinase inhibitor cross-talk effects on migration of Her2-overexpressing mammary epithelial cells. Molecular Pharmacology 73 1668-1678.

Lane AJP \& Wathes DC 1998 An electronic nose to detect changes in perineal odors associated with estrus in the cow. Journal of Dairy Science 81 2145-2150.

Langhout DJ, Spicer LJ \& Geisert RD 1991 Development of a culture system for bovine granulosa cells: effects of growth hormone, estradiol, and gonadotropins on cell proliferation, steroidogenesis, and protein synthesis. Journal of Animal Science 69 3321-3334.

Luck MR, Rodgers RJ \& Findlay JK 1990 Secretion and gene expression of inhibin, oxytocin and steroid hormones during the in vitro differentiation of bovine granulosa cells. Reproduction, Fertility, and Development 2 11-25.

Mamluk R, Greber Y \& Meiden R 1999 Hormonal regulation of messenger ribonucleic acid expression for steroidogenic factor-l, steroidogenic acute regulatory protein and cytochrome P450scc in bovine luteal cells. Biology of Reproduction 60 628-634.

deMoura MD, Choi D, Adashi EY \& Payne DW 1997 Insulin-like growth factor-I mediated amplification of follicle-stimulating hormonesupported progesterone accumulation by cultured rat granulosa cells: enhancement of steroidogenic enzyme activity and expression. Biology of Reproduction 56 946-953.

Mihm M \& Evans ACO 2008 Mechanisms for dominant follicle selection in monovulatory species: a comparison of morphological, endocrine and intraovarian events in cows, mares and women. Reproduction in Domestic Animals 43 48-54. 
Mihm M, Good TEM, Ireland JLH, Ireland JJ, Knight PG \& Roche JF 1997 Decline in serum follicle-stimulating hormone concentrations alters key intrafollicular growth factors involved in selection of the dominant follicle in heifers. Biology of Reproduction 57 1328-1337.

Mihm M, Austin EJ, Good TEM, Ireland JLH, Knight PG, Roche JF \& Ireland JJ 2000 Identification of potential intrafollicular factors involved in selection of dominant follicles in heifers. Biology of Reproduction $63811-819$

Miller TM, Tansey MG, Johnson EM Jr \& Creedion DJ 1997 Inhibition of phosphotidyl inositol-3-kinase activity blocks depolarization and insulin like growth factor-I mediated survival of cerebellar granule cells. Journal of Biological Chemistry 272 9847-9853.

Minegishi T, Hirakawa T, Kishi H, Abe K, Abe Y, Mizutani T \& Miyamoto K $2000 \mathrm{~A}$ role of insulin-like growth factor I for follicle-stimulating hormone receptor expression in rat granulosa cells. Biology of Reproduction 62 325-333.

Monget P, Monniaux D, Pisselet C \& Durand P 1993 Changes in insulin-like growth factor I (IGF-I), IGF-II and their binding proteins during growth and atresia of ovine ovarian follicles. Endocrinology 132 1438-1446.

Oltivai ZN, Milliman CL \& Korsmeyer SJ 1993 Bcl-2 heterodimerizes in vivo with a conserved homolog, Bax, that accelerates programmed cell death. Cell 74 609-619.

Perks CM, Peters AR \& Wathes DC 1999 Follicular and luteal expression of insulin-like growth factors I and II and the type 1 IGF receptor in the bovine ovary. Journal of Reproduction and Fertility 116 157-165.

Poretsky L, Cataldo NA, Rosenwaks Z \& Giudice LC 1999 The insulinrelated ovarian regulatory system in health and disease. Endocrine Reviews 20 535-582.

Quirk SM, Cowan RG, Harman RM, Hu C-L \& Porter DA 2004 Ovarian follicular growth and atresia; the relationship between cell proliferation and survival. Journal of Animal Science 82 E40-E52.

Richards J 1994 Hormonal control of gene expression in the ovary. Endocrine Reviews 15 725-751.

Richards JS, Russell DL, Ochsner S, Hsieh M, Doyle KH, Falender AE, Lo YK \& Sharma SC 2002 Novel signalling pathways that control ovarian follicular development, ovulation and luteinization. Recent Progress in Hormone Research 57 195-220.

Roberts AJ \& Echternkamp SE 1994 In vitro production of estradiol by bovine granulosa cells: evaluation of culture condition, stage of follicula development and location of cells within follicles. Biology of Reproduction 51 273-282.

Le Roith D 2003 The insulin-like growth factor system. Experimental Diabetes Research 4 205-212.

Le Roith D, Werner H, Beitner-Johnson D \& Roberts CT 1995 Molecular and cellular aspects of the insulin like growth factor-I receptor. Endocrine Reviews 16 143-163.

Ryan KE, Casey SM, Canty MJ, Crowe MA, Martin F \& Evans AC 2007 Akt and Erk signal transduction pathways are early markers of differentiation in dominant and subordinate ovarian follicles in cattle. Reproduction 133 617-626.

Ryan KE, Glister C, Lonergan P, Martin F, Knight PG \& Evans AC 2008 Functional significance of the signal transduction pathways Akt and Erk in ovarian follicles: in vitro and in vivo studies in cattle and sheep. Journal of Ovarian Research 12.

Saumande J 1991 Culture of bovine granulosa cells in a chemically defined serum-free medium: the effect of insulin and fibronectin on the response to FSH. Journal of Steroid Biochemistry and Molecular Biology 38 189-196.

Schams D, Koll R \& Li CH 1988 Insulin-like growth factor-1 stimulates oxytocin and progesterone production by bovine granulosa cells in culture. Journal of Endocrinology 116 97-100.

Siddle K, Ursø B, Niesler CA, Cope DL, Molina L, Surinya KH \& Soos MA 2001 Specificity in ligand binding and intracellular signalling by insulin and insulin-like growth factor receptors. Biochemical Society Transactions 29 513-525.

Silva JM \& Price CA 2002 Insulin and IGF-I are necessary for FSH-induced cytochrome P450 aromatase but not cytochrome P450 side-chain cleavage gene expression in oestrogenic bovine granulosa cells in vitro. Journal of Endocrinology 174 499-507.

Silva JM, Hamel M, Sahmi M \& Price CA 2006 Control of oestradiol secretion and of cytochrome P450 aromatase messenger ribonucleic acid accumulation by FSH involves different intracellular pathways in oestrogenic bovine granulosa cells in vitro. Reproduction 132 909-917.
Silverman L, Eimerl S \& Orly L 1999 CCAAT enhancer binding protein beta and GATA-4-binding regions within the promoter of the steroidogenic acute regulatory protein (StAR) gene are required for transcription in rat ovarian cells. Journal of Biological Chemistry 274 17987-17996.

Spicer LJ \& Echternkamp SE 1995 The ovarian insulin and insulin-like growth factor system with an emphasis on domestic animals. Domestic Animal Endocrinology 12 223-245.

Spicer LJ, Alpizar E \& Echternkamp SE 1993 Effects of insulin, insulin-like growth factor-I, and gonadotropins on bovine granulosa cell proliferation, progesterone production, estradiol production, and (or) insulin-like growth factor-I production in vitro. Journal of Animal Science 71 1232-1241.

Spicer LJ, Alpizar A \& Stewart RE 1994a Evidence for an inhibitory effect of insulin-like growth factor-I and II on insulin-stimulated steroidogenesis by nontransformed ovarian granulosa cells. Endocrine 2 735-739.

Spicer LJ, Alpizar E \& Vernon RK 1994b Insulin-like growth factor-I receptors in ovarian granulosa cells: effect of follicle size and hormones. Molecular and Cellular Endocrinology 102 69-76.

Spicer LJ, Chamberlain CS \& Maciel SM 2002 Influence of gonadotropins on insulin and insulin-like growth factor-I induced steroid production by bovine granulosa cells. Domestic Animal Endocrinology 22 237-254.

Taya K, Kaneko H, Watanabe G \& Sasamoto S 1991 Inhibin and secretion of FSH in oestrus cycles of cows and pigs. Journal of Reproduction and Fertility Supplement 43 151-162.

Ui M, Shimonaka M, Shimasaki S \& Ling N 1989 An insulin-like growth factor-binding protein in ovarian follicular fluid blocks follicle-stimulating hormone-stimulated steroid production by ovarian granulosa cells. Endocrinology 125 912-916.

Urban RJ, Garmey JC, Shupnik MA \& Veldhuis JD 1990 Insulin-like growth factor type-I increase concentrations of mRNA encoding CYP450scc enzyme in primary cultures of porcine granulosa cells. Endocrinology 127 2481-2488.

Urban RJ, Shupnik AM \& Bodenburg YH 1994 The insulin-like growth factor-I increases expression of porcine P-450 cholesterol side chain cleavage gene through a GC-rich domain. Journal of Biological Chemistry 269 25761-25769.

Veldhuis JD, Rodges RJ, Dee A \& Simpson ER 1986 The insulin-like growth factor, somatomedin $\mathrm{C}$, induces the synthesis of cholesterol side-chain cleavage cytochrome P450 and adrenodoxin in ovarian cells. Journal of Biological Chemistry 261 2499-2502.

Wathes DC, Perks CM, Davis AJ \& Denning-Kendall PA 1995 Regulation of insulin-like growth factor-I and progesterone synthesis by insulin and growth hormone in the ovine ovary. Biology of Reproduction $\mathbf{5 3}$ 882-889.

Wathes DC, Taylor VJ, Cheng Z \& Mann GE 2003 Follicle growth, corpus luteum function and their effects on embryo development in postpartum dairy cows. Reproduction Supplement 61 219-237.

Webb R, Garnsworthy PC, Gong J-G \& Armstrong DG 2004 Control of follicular growth; local interactions and nutritional influences. Journal of Animal Science 82 E63-E74.

Williams GT \& Smith CA 1993 Molecular regulation of apoptosis: genetic controls on cell death. Cell 74 777-779.

Wrathall JHM \& Knight PG 1993 Production of immunoactive inhibin by bovine granulosa cells in serum-free culture: effects of exogenous steroids and FSH. Domestic Animal Endocrinology 10 289-304.

Yang MY \& Rajamahendran R 2000 Morphological and biochemical identification of apoptosis in small, medium, and large bovine follicles and the effects of follicle-stimulating hormone and insulin-like growth factor-I on spontaneous apoptosis in cultured bovine granulosa cells. Biology of Reproduction 62 1209-1217.

Zheng X, Price CA, Tremblay Y, Lussier JG \& Carrière PD 2008 Role of transforming growth factor- $\beta 1$ in gene expression and activity of estradiol and progesterone-generating enzymes in $\mathrm{FSH}$-stimulated bovine granulosa cells. Reproduction 136 447-457.

Received 12 February 2009

First decision 23 March 2009

Revised manuscript received 2 October 2009

Accepted 9 October 2009 